\title{
Memórias gramaticais: João Ribeiro para jovens e crianças
}

Grammatical memories: João Ribeiro for children and youth

Leonor Lopes Fávero

Pontifícia Universidade Católica de São Paulo, Universidade de São Paulo, São Paulo, SP, Brasil

Márcia A. G. Molina

Universidade Federal do Maranhão, São Luís, MA, Brasil

Resumo: Este trabalho busca resgatar as memórias gramaticais de João Ribeiro, em duas obras: Gramática Portuguesa (Curso Primário) e Gramática Portuguesa (Curso Superior), produzidas no final do século XIX e início do século XX, quando se começou a pensar a criança não mais como um adulto em miniatura. Analisamos nas obras as suas Considerações Iniciais, Morfologia e Sintaxe, apoiadas na História Cultural e História das Ideias Linguísticas. Percebemos que ambas são semelhantes na abordagem dos tópicos, mas que o autor discorre sobre eles mais minuciosamente na obra dirigida a jovens. Além disso, ambas ora estão ancoradas nas obras de influência filosófica ora nas de orientação histórico-comparada, trazendo, a de Curso Primário, exercícios e ilustrações.

Palavras-chave: Gramática Portuguesa (Curso Superior). Gramática Portuguesa (Curso Primário). João Ribeiro. História cultural. História das Ideias Linguísticas.

Abstract: This study recovers João Ribeiro's grammatical memories in two works: Gramática Portuguesa (Curso Primário) and Gramática Portuguesa (Curso Superior), produced in the late nineteenth and early twentieth centuries, when the child was not seen as a miniature adult anymore. The Initial Considerations, Morphology and Syntax of both works are analyzed with the support of Cultural History and History of Linguistic Ideas. The analysis shows that both books are similar in their approach to the topics, but the author discusses them in more detail in the work addressed to the youth. Also, one can conclude from the analysis that both books are anchored either in the works of philosophical influence or in works of historical-comparative orientation; in particular, the Gramática Portuguesa (Curso Primário) presents exercises and illustrations.

Keywords: Gramática Portuguesa (Curso Primário). Gramática Portuguesa (Curso Superior). João Ribeiro. Cultural history. History of Linguistic Ideas. 
Leonor Lopes

Fávero

Márcia A. G. Molina

\section{Considerações iniciais}

Ricoeur, em La mémoire, l'histoire et l'oubli (2000), alerta para os benefícios da busca de uma "política da justa memória", inserindo as possibilidades de uma memória "esclarecida pela historiografia" e a de uma historiografia profissional passível de "reanimar uma memória declinante" (p. I). Já Pollak (1989) tem desenvolvido estudos apontando aspectos mais específicos que se referem ao uso da memória como fonte histórica. É sob essa concepção que utilizamos aqui o termo, tomando como fonte não o relato, mas o documento escrito, constituindo este nosso instrumento para resgatar aquele momento histórico e nele o autor João Ribeiro e sua produção gramatical.

Sabemos que no final do século XIX ocorria no Brasil uma importante mudança em nossa política: o país passava do regime monárquico ao republicano. Com a República, instaurou-se uma crucial necessidade de apagamento do passado, já que a Monarquia era vista por muitos como modelo de atraso, aculturação e dependência. A nova época pedia a modernidade em todos os setores, especialmente na escola, porque se entendia que ser escolarizado era sinônimo de cidadão, aquele que, por exemplo, podia eleger seu governante, uma vez que somente os homens alfabetizados tinham o direito a voto.

Além disso, muitas correntes filosóficas iluminavam o pensamento dos intelectuais brasileiros, como o Positivismo, de August Comte, e o Evolucionismo, de Darwin e Spencer. Paralelamente, surgiam os primeiros estudos de Psicologia, mostrando que a criança, diferentemente do compreendido até então, não era um adulto em miniatura, exigindo a elaboração de material didático especialmente adequado a ela. É nesse momento histórico que se situa o trabalho. Pretendemos discorrer sobre duas importantes gramáticas de língua portuguesa adotadas no Brasil durante o primeiro período republicano, surgidas depois da de Júlio Ribeiro (1881) e do Programa de Exames, elaborado pelo professor Fausto Barreto do Colégio Pedro II, em 1887, uma destinada à infância, Gramática Portuguesa: Curso Primário, dedicada à primeira infância, e outra intitulada Gramática ${ }^{1}$ Portuguesa (Curso Superior), idealizada para alunos que ingressavam no que na época era chamado de Curso Superior².

Procedemos à atualização ortográfica para facilitar a leitura.

2 Não temos hoje o similar, mas, a título de ilustração, o aluno saía do Curso Primário, ingressava no Superior, com duração de sete anos e, depois dele concluído, adquiria (precocemente) o título de Bacharel em Letras e poderia ingressar nos cursos superiores oferecidos na ocasião: 
Entendendo o estudo dessas obras como parte de nossa história cultural, e, à luz da História das Ideias Linguísticas no Brasil, pretendemos observar de que forma foram pensadas, compreendidas e produzidas; para isso, e dadas as limitações de um trabalho desta natureza, selecionamos, para análise das obras, as partes que compreendem as Noções Gerais (Introdução e Prolegômenos), a Morfologia e a Sintaxe.

Objetivamos não apenas historiar nosso passado, mas recuperá-lo, para que possamos inscrevê-lo em nossa memória gramatical.

Além disso, ao final do trabalho, pretendemos deixar implícito que, ao recuperarmos a história de um livro antigo, não estamos somente resgatando o passado, mas procurando melhor compreender um dado momento histórico, já que as obras foram produzidas por um homem inscrito numa sociedade, dela recebendo influências, nela refleMemórias gramaticais tindo suas convicções. As gramáticas surgidas na ocasião, como feitas por e para aqueles homens, acabam por delinear o período em que nos foram dadas a ler: no caso, momento conturbado, de muitas transformações político-sociais e, por consequência, de instabilidade de várias ordens.

Procuraremos, para isso, resgatar o diálogo entre o autor e as correntes que iluminavam os estudiosos daquele momento histórico, pois, como diz Bakhtin (1975, p. 100):

\footnotetext{
Um enunciado vivo, significativamente surgido em um momento histórico e em um meio social determinado, não pode deixar de tocar em milhares de fios dialógicos vivos, tecidos pela consciência sócio-ideológica em torno do objeto de tal enunciado e de participar ativamente do diálogo social. Do resto, é dele que o enunciado saiu: ele é como sua continuação, sua própria réplica.
}

e avaliar como o próprio autor entendia que deveria ser uma obra para jovens e uma para crianças.

O trabalho está assim organizado: primeiramente, discorreremos sobre o autor João Ribeiro, visto que, como diz Foucault, falar do autor é falar da obra. Depois, analisaremos a obra dirigida para o Curso Superior e, depois, a dirigida para o Curso Primário. Nas Considerações Finais, discorreremos sobre como o autor dialogou com as correntes

Direito, Engenharia e Medicina. 
que o iluminavam, o objetivo de seus compêndios e o que as obras têm de diferente entre si.

\section{0 autor}

João Batista Ribeiro de Andrade nasceu em Laranjeiras (SE) em 1860 e morreu no Rio de Janeiro em 1934. Foi criado por seu avô, com quem

Leonor Lopes

Fávero

Márcia A. G. Molina desenvolveu o hábito pela leitura e granjeou forte influência positivista. Fez os primeiros estudos em sua terra natal, ingressando depois na Faculdade de Medicina de Salvador, curso abandonado, tal e qual o que aconteceu com o de Engenharia iniciado no Rio de Janeiro. Foi jornalista, tendo colaborado com inúmeros jornais e revistas, além de professor de História e diretor do Colégio Pedro II. Escreveu inúmeras obras de caráter filológico, entre as quais se destacam as que são objeto de análise neste trabalho.

\section{Gramática Portuguesa (Curso Superior)}

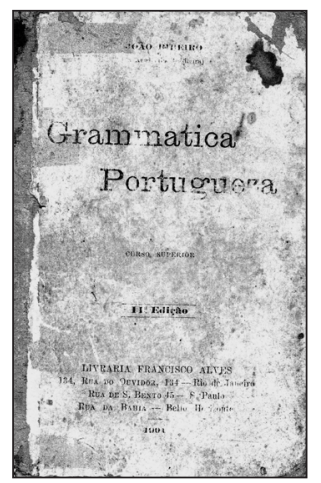

Figura 1 - Capa da Gramática Portuguesa (Curso Superior)

Essa gramática, editada pela primeira vez em 1887, está calcada no programa de exames traçado por Fausto Barreto e foi adotada alguns anos após sua publicação pelos professores do Colégio Pedro $\mathrm{II}^{3}$. A edição consultada é a $11^{\mathrm{a}}$ e data de 1904 . Como as edições de suas obras divergem muito entre si, esta apresenta as seguintes divisões: Introdução, Prolegômenos, Classificação, Sintaxe e Estudos Complementares.

3 De acordo com o Programa de ensino da escola secundária brasileira (VECHIA; LORENZ, 1998), a primeira adoção da obra pelo colégio data de 1892. 
Na Introdução, noticia a origem e a formação da Língua Portuguesa, exibindo uma vasta relação de línguas, cujas palavras trouxeram "um novo subsídio ao vocabulário da língua da metrópole" (p. XIV): o germânico, o árabe, o francês, o italiano, o inglês, o alemão, o espanhol, o céltico, o hebraico, o russo, o húngaro, o turco e o persa, acrescentando ainda o asiaticismo, com termos emprestados tanto da China quanto da Índia. Soma-se à lista também o americanismo, relacionando palavras oriundas das repúblicas espanholas e do tupi-guarani. 0 arcaísmo e o neologismo estão igualmente mencionados, revelando a importância dada ao vernáculo e ao conhecimento histórico da língua. Finaliza esse item introdutório, apontando que os escritores brasileiros muito têm contribuído para a riqueza de nossa língua e que, entre as "modernas" criações lexicais, as mais "defeituosas" proveem do hibridismo.

Memórias gramaticais evolucionista, que permeava todas as áreas do saber na ocasião, acreditavam que uma das maneiras de ocorrer a morte de um vocábulo era sua substituição por uma nova palavra. Julgavam ainda que os hibridismos conspurcavam o idioma, porque deixavam as palavras impuras, posicionando-se, como João Ribeiro, avessos a eles.

Desse tópico introdutório, seguem-se os Prolegômenos, nos quais João Ribeiro define a gramática como "coordenação das fórmulas, leis ou regras da linguagem literária ou polida", esclarecendo que tal explicação decorre da "observação dos fatos da linguagem" e que o objeto da gramática é sempre o "grupo de palavras e a regra respectiva" (p.3). Em tal exposição, podemos vislumbrar, sob o discurso da "ciência", o papel prescritivo que o autor confere à gramática no geral e, em particular, a seu compêndio gramatical.

Prosseguindo, informa, amparado nos ditames do modelo das obras de inspiração filosófica, que a gramática divide-se em geral e particular. A primeira é a que expõe os "princípios lógicos da linguagem", podendo ser "comum a muitas ou a todas as linguagens". A segunda é a que fornece "os princípios e as particularidades especiais de cada idioma". Em seguida, e agora atrelado aos preceitos da corrente cientificista, define a gramática histórica como a que "estuda os fatos da língua em seus diversos períodos"; e a comparativa, como a que analisa os fatos comuns ou diferentes, em grupo de línguas que têm a mesma origem (p. 3). Outrossim, acrescenta que esta não pode ser desvinculada daquela, já que constituem a aplicação do método "histórico-comparativo" (p. 3 e 4). 
Leonor Lopes

Fávero

Márcia A. G. Molina

Preconiza, ainda, que gramática descritiva ou expositiva (ou ainda prática) é "a arte que ensina a falar e a escrever corretamente, isto é, segundo o uso das pessoas doutas". Em tal conceituação, ouve-se a voz de gramáticos anteriores, como João de Barros (1540, p. 293), para quem "[Gramática] é um modo certo e justo de falar e escrever colheito do uso e autoridade dos barões doutos" e Reis Lobato (1770, p. 1), que afirma ser a Gramática "a arte que ensina a falar sem erros a oração portuguesa". Quando assevera "falar sem erros", quer dizer de acordo com o padrão culto.

Continuando, frisa que a gramática portuguesa divide-se em quatro partes principais: fonologia, "o estudo dos sons que compõem a palavra" (p. 4), morfologia, "o estudo do vocábulo considerado como composto de elementos significativos" (p. 5), classificação ou taxinomia, “a distribuição dos vocábulos por famílias e espécies, segundo o sentido" (p. 5) e, finalmente, sintaxe, o "estudo dos vocábulos em coordenação, isto é, considerados na frase" (p. 5).

Essa quadripartição dos estudos gramaticais é herança medieval, desde Prisciano.

Na sequência, passa para a primeira parte de sua obra ${ }^{4}$, que chama de $O$ vocábulo e compreende a Classificação (taxinomia) e o Estudo das formas e variações de formas (morfologia), sobre as quais discorreremos a seguir.

\section{Classificação}

João Ribeiro inicia o capítulo justificando o emprego do termo Taxinomia, assim se posicionando:

Pode parecer a muitos mal soante ou excêntrico o vocábulo taxinomia. Impróprio ou desnecessário é que o não é. Basta a propósito lembrar que os gramáticos antigos classificavam os vocábulos em suas categorias lógicas sob o título Etimologia (!). E será este menos helênico que o outro? (p. 11).

apontando desde logo sua filiação à escola tradicional. Além disso, não havia à época uma uniformização no emprego desses termos, portanto ganhavam eles, de acordo com o estudioso que os empregava,

4 Como em outras obras do período, não se observa minucioso rigor na partição dos capítulos. Essa primeira parte é, na realidade, a segunda, se não contarmos a Introdução, que noticia a origem e a formação da Língua Portuguesa. 
colorido diferente. Nosso autor, por exemplo, ensina-nos que, na boa classificação, "a lógica determina que se observe a subordinação dos caracteres; isto é, os caracteres mais importantes são os que devem servir de base à classificação" (p. 11).

Para a classificação, norteia-se na forma histórica, estudando os vocábulos primitivos e derivados, na quantidade extensiva, analisando seu número de sílabas, na variação, detendo-se nas palavras variáveis e invariáveis, na comparação, ensinando sinônimas e homônimas, e, a parte que julga menos fastidiosa, na que traz o léxico, mostrando-nos as palavras que indicam os seres (substantivos) e as ações (verbos), asseverando que essa discriminação é a que mais serve aos estudos gramaticais (p. 13).

Prossegue, discutindo as palavras variáveis: o substantivo, o qualificativo, o determinativo, o pronome, o verbo e suas espécies; depois, Memórias gramaticais discorrendo sobre os vocábulos invariáveis, ensina o advérbio, a conjunção, a preposição e a interjeição, totalizando nove classes gramaticais.

Em relação a essa parte, diz-nos que os adjetivos,

\footnotetext{
na comum opinião dos gramáticos, dividem-se em duas grandes classes nominais (ou qualificativos) e pronominais (ou determinativos), porém que é totalmente disparatada e ilógica a reunião dos qualificativos e determinativos no mesmo grupo, com o nome de adjetivos. (FÁVERO; MOLINA, 2008, p. 17).
}

$\mathrm{Na}$ classe de Pronome, considera somente os pessoais, apontando sua aproximação com o latim: "os pronomes pessoais conservam os vestígios da declinação que tinham no latim: d'ali as variações que sofrem em todas as pessoas" (p. 25).

Ao estudar os verbos, informa: "é a palavra pela qual pode uma ação. Estado ou qualidade ser atribuída a um ser" (p. 29), lembrando em nota que "materialmente o verbo se divide em duas partes: o radical, que representa a ideia principal, e a desinência, que sempre é variável e exprime a ideia acessória" (p. 29). Lembremo-nos de que, anos mais tarde, Mattoso Câmara Jr. (1969) lembrar-se-ia de que esse autor fora o que com mais rigor sistematizara o estudo dos verbos.

Ancorado na gramática tradicional, João Ribeiro assevera: "Existe um verbo único que não tem ideia atributiva, isto é, o atributo vem d'ele sempre separado e este verbo apenas exprime a existência ou absoluto. É o chamado verbo substantivo: ser" (p. 31). 
Seguem-se os advérbios, preposições, conjunções e interjeições, sem que nada de novo tivesse sido observado.

Depois dessa parte, a obra apresenta uma outra em que avalia as famílias e grupos de palavras (sinônimos, homônimos e parônimos), ancorado agora no princípios da Gramática Histórico-Comparativa. Vale ressaltar que, ao relacionar vocábulos e famílias, o autor utiliza-se do símbolo

Leonor Lopes

Fávero

Márcia A. G.

Molina

56

\section{matemático $\sqrt{ }$ (de raiz):}

$$
\sqrt{ } \mathrm{FL} \text { - correr }
$$

$\begin{aligned} & \text { Fluxo } \\ & \text { Fluir } \\ & \text { Afluente } \\ & \text { Chuva [...] (p. 40). }\end{aligned}$
.

Num outro capítulo, intitulado Estudo da Formação dos Vocábulos (Morfologia), discute a estrutura, raiz e afixos dos vocábulos (parte I), bastante ancorado nos princípios da escola histórico-comparativa; e sua flexão em gênero, número e, ancorado novamente no modelo latino, traz o caso (parte II).

Na sequência, historia o gênero, o número e os vestígios deixados pelas declinações latinas no português, espanhol e francês. Ao discorrer sobre grau, informa: "Os substantivos comuns ou apelativos e os adjetivos qualificativos são susceptíveis de grau." (p. 73).

Ribeiro continua essa parte com a flexão do verbo, trazendo paradigmas de conjugações dos auxiliares, regulares, irregulares e algumas conjugações especiais, como a das formas compostas e pronominais. Nesse item, já aponta para diferenças entre a linguagem popular e os clássicos: "Na linguagem popular (e ainda nos clássicos) encontram-se às vezes orações impessoais, tendo apesar disto expresso [...]." (p. 113).

Seguem-se os estudos de derivação e composição, relacionando uma série de prefixos e sua significação, apontando, amparado nas correntes de inspiração científica: "Convém lembrar que alguns prefixos gregos sofreram alterações fonéticas na evolução da língua [...].” (p. 127). Encerra com um minucioso estudo da derivação, trazendo, como fizera anteriormente, um rol de sufixos e suas significações. Termina essa parte examinando as palavras variáveis e invariáveis formadas no seio de nossa língua. 


\section{Sintaxe}

A segunda parte de sua obra (que na realidade é a terceira) intitulase Sintaxe (o estudo da proposição), iniciada com a definição do termo: "Sintaxe é a parte da gramática em que se estudam os vocábulos e os grupos de vocábulos considerados em conjunto no discurso" (p. 145), separando esses estudos em duas partes: "sintaxe das palavras" e "sintaxe das proposições".

Segue uma análise da concordância "do sujeito com o verbo e do complemento ou atributo com o sujeito e até com o verbo" (p.147) e um estudo sintático de todas as classes de palavras, imprimindo ao estudo Memórias do verbo maior densidade, analisando suas funções, emprego, correlação de tempos verbais e sintaxe de cada uma das formas nominais. Recordemo-nos de que as gramáticas filosóficas atribuíam a essa classe um valor especial, considerando-a a palavra por excelência. ${ }^{5}$

Depois ressalta alguns casos que, segundo ele, apresentavam dificuldades na concordância, priorizando, então, três regras lógicas de gramática geral que, aplicáveis a todas as línguas cultas, serviriam de recurso prático ao estudante iniciante (p. 210):

$1^{1}$ - Dois ou mais sujeitos equivalem a um sujeito do plural;

$2^{\circ}$ - Dois ou mais substantivos de diferentes gêneros equivalem a um substantivo masculino do plural;

3-ㅡㄹ concorrência de várias pessoas, a segunda é preferida à terceira $\mathrm{e}$ a primeira a todas as outras.

Destacamos aqui que sua referência à gramática geral revela apego às obras de influência filosófica e sua atenção às regras, mais uma vez, o papel prescritivo atribuído à obra.

Dando prosseguimento, apresenta-nos um breve estudo da concordância com o verbo haver e com o pronome "se" e alguns de seus empregos especiais (p. 216-221). Esses temas eram motivo de discussão entre os estudiosos na época, especialmente no caso do $s e$, havendo os que se posicionavam a favor de compreender a partícula como índice de indeterminação do sujeito, funcionando como o "on" francês, e os que acreditavam ser ela um pronome.

5 Veja-se, por exemplo, a Grammaire de Port-Royal. 
Leonor Lopes

Fávero

Márcia A. G. Molina

Mais à frente, no mesmo capítulo e coerentemente com o propósito do compêndio, trata da ordem e da colocação das palavras em geral, tanto no período simples quanto no composto, esmiuçando o estudo da segunda. Depois, é a vez de revisar as figuras de sintaxe e as partículas de realce, discussões esperadas para a época.

Examina a anacolutia, asseverando que essa interrupção, "não raras vezes, elegantíssima, traduz mais fielmente o pensamento do que a coordenação lógica por si mesma despida de sentimento" (p. 241). 0 fato de a valorizar, analisando-a separadamente, pareceu-nos digno de destaque, porque, para vários estudiosos, ela constituiria vício e não figura. Somente depois é que traz os vícios de linguagem, destacando tanto os galicismos quanto a ambiguidade e os arcaísmos sintáticos, utilizando um subcapítulo para cada um dos fenômenos. Em relação ao galicismo, informa ser "dever de todos que falam e escrevem zelar a pureza de nosso idioma [...] é a França a pátria dos modelos em letras e em ciências para países secundários que não têm movimento literário original" (p. 251).

Ressaltamos aqui sua postura evolucionista, considerando que o galicismo iria conspurcar nosso idioma, e, ao mesmo tempo, uma crítica a nossos movimentos literários, todos, até então, de inspiração europeia.

Finaliza essa parte tratando da análise lógica das frases, investigando as relações predicativa, atributiva e adverbial e as proposições simples, complexas subordinadas: substantivas, adjetivas e adverbiais, compostas sindéticas e assindéticas, contratas e elípticas. Minucioso estudo, portanto.

\section{Estudos complementares}

Tal capítulo está dividido em três partes: fonologia, etimologia e semântica. Dada a delimitação de nosso trabalho, trataremos somente da etimologia.

\section{Etimologia}

O autor inicia informando os princípios nos quais se baseara: filiação e comparação, pontuando sua filiação ao método histórico-comparativo que iluminava a maioria dos estudiosos da época.

Depois, esclarece que filiação é a "história dos vocábulos, a re-

ferência e ligação da forma atual com a forma primitiva" (p. 338); e a 
comparação para ele se consistiria "em notar a uniformidade ou dessemelhança de processos e de fatos em certo grupo de línguas" (p. 339).

Finalizando, o autor estuda a etimologia dos substantivos, artigos, determinativos, pronomes, formas verbais (comparando a conjugação latina com a portuguesa), advérbios, preposições e conjunções.

\section{Gramática Portuguesa (Curso Primário - 1ํo ano de Por- tuguês)}

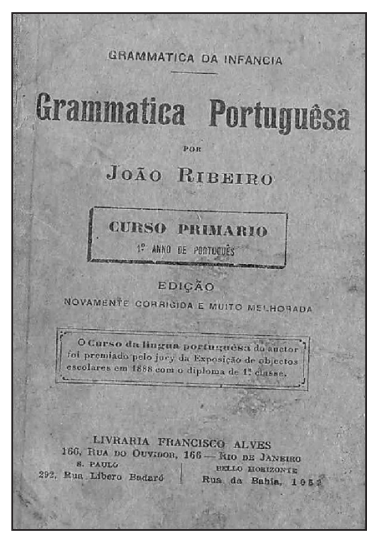

Memórias

gramaticais

Figura 2 - Capa da Gramática Portuguesa (Curso Primário)

Essa obra foi editada pela primeira vez em 1888, corrigida e melhorada pelo autor diversas vezes, mas sempre pensada para o público infantil, atendendo crianças, estimadamente, de até 11 anos, quando ascendiam ao Curso Superior. A edição analisada é a 94ª e data de 1936.

Dois fatos devem ser destacados aqui: na ocasião da escritura dessa obra, com o desenvolvimento da psicologia e da pedagogia, começava-se a pensar a criança não mais como um "serzinho" sem importância familiar ou, quando um pouquinho mais velha, "adulto em miniatura", mas dotada de capacidades peculiares e específicas, dependendo da faixa etária:

Há por toda parte um profundo interesse pela educação das crianças. A pedagogia é uma preocupação contínua. Congressos, livros, conferências, decretos, legislações aparecem dia a dia para cuidar da sorte desta meninada que surge. A sua felicidade é a ânsia dos pedagogos [...]. Efetivamente este pequeno ser, este bichinho lá para o fundo dos gineceus, na sua barulhosa con- 
corrência com os animaizinhos domésticos, ocupara tão grande lugar no pensamento humano, despertara um tão decisivo cuidado de escritores ilustres. (CARNEIRO LEÃO, 1917, p. 94-95).

Leonor Lopes

Fávero

Márcia A. G. Molina

Por causa dessa nova forma de se perceber a criança, precisava ela de material especialmente dirigido para sua tenra idade.

$\mathrm{O}$ outro fato a ser revelado é que começavam a circular aqui no Brasil as ideias da Escola Nova, corrente que procurava mudar o rumo da Educação, dando-lhe sentido vivo e ativo (LUZURIAGA, 1970).

João Ribeiro, então, traz a público esse compêndio, explicitando-o numa separata com uma série de exercícios propostos para cada unidade ensinada:

Escrever certo, falar certo, compor frases, seis em poucas palavras o objeto do ensino gramatical, e os instrumentos naturais desse saber são o ditado e a prática de escrever, a conversação, a recitação e declamação e ao lado da análise do pensamento o estudo da sinonímia, da redação com elementos oferecidos pelo mestre. Neste sentido preparamos um livro de Exercícios que serve de complemento a esta gramática. (p. 7).

Depois, começa a exposição da matéria, apresentando a divisão da gramática tal qual a encontrada em sua Gramática Portuguesa (Curso Superior), ou seja, em quatro partes, mas organizada de forma diferente, tratando dos sons, das formas, da classificação das palavras e da composição delas no discurso.

Fávero (1996, p. 94) ensina:

A divisão da gramática com quatro partes vem desde o período medieval (talvez desde Prisciano, que foi o primeiro a reconhecer a existência de uma sintaxe que é o estudo da 'disposição que visa à obtenção da oração perfeita' com Alexandre de Villedieu (Doctrina epuerorum,1200): ortografia, etimologia, diasintástica (= sintaxe) e prosódia, divisão essa que permanece até o século XVI ou até mais porque ainda se encontra, em fins do século XVIII, por exemplo em Soares Barbosa).

Na sequência, parte para a Classificação, que passamos a revisar. 


\section{Classificação}

Inicia essa parte inscrevendo as palavras em dois grupos: quanto à formação (palavras primitivas e derivadas) e quanto à variação e mudanças (palavras variáveis e invariáveis). Informa, contudo, que a classificação mais importante é o que se faz dividindo as palavras em classes ou categorias conforme o sentido, inscrevendo-as tal como o fizera em sua obra para o Curso Superior, em nove categorias: substantivos, qualificativos, determinativos, pronomes, verbos, advérbios, preposições, conjunções e interjeições.

Em nota, informa que as palavras também poderiam ser classificadas de acordo com os seguintes grupos: sinônimos, antônimos e homônimos (homófonos e homógrafos) e parônimos. Na obra para o Curso Superior, ensinara esse conteúdo em Família ou Grupos de Palavras. Julgamos Memórias gramaticais que, na obra para crianças, apenas mencionou em nota tal conteúdo, para, de um lado, muito possivelmente, não sofrer críticas da comunidade pela omissão e, de outro, deixar o tópico pincelado para os jovens curiosos que desejassem buscar seu conhecimento.

Ressalte-se que, embora tivesse mencionado a elaboração de um adendo com exercícios, oferece, ao final desse tópico, uma relação de 92 palavras a serem classificadas conforme o conteúdo exposto.

Parte depois para a classificação dos vocábulos, conforme sua categoria. No estudo do substantivo, digna de nota é a conceituação dos abstratos: "são os que representam seres que só existem na imaginação [...] também exprimem qualidades ou propriedades da coisa" (p. 27). Buscando compreender o material à luz de seu tempo, analisamos seus pares e constatamos que nenhum apresentou definição tão ampla. Tampouco o fez o próprio autor no material produzido para os de mais idade. Nesta, ensina: “Abstratos: são os seres que só existem na imaginação, no pensamento do homem.” (p. 13). Pensamos que, por ser dedicada à criança, o autor buscou "esmiuçar" o termo.

No estudo dos determinativos, devemos fixar nosso olhar em dois fatos: primeiramente, na conceituação do termo determinativos: "servem para estabelecer distinções e para notar uma ou várias coisas d'entre muitas" (p. 31), ou seja, no afã de simplificar, o autor nada esclareceu. Mais pontual foi em sua gramática para o Curso Superior: determinativos: "são os que marcam a referência dos nomes sem indicar nenhuma qualidade. Também se chamam pronominais" (p. 19). Uma outra lição da gramática para crianças merece nossa atenção: "Podem 
Leonor Lopes

Fávero

Márcia A. G. Molina

ser considerados possessivos ou gentílicos aqueles que indicam pátria: francês, franco, americano, brasileiro, fluminense, inglês, etc." (p. 31). Essas considerações revelam que, para ele, francês significa natural da França, inglês, natural da Inglaterra e assim sucessivamente. Quando discorre sobre o verbo, não é o seu conceito que oferece, mas o de proposição: "É a reunião de palavras formando sentido completo constituída por dois termos: sujeito e predicado" (p. 37), inserindo, inclusive, noção sintática. ${ }^{6}$ Julgamos que, acertadamente, atribuísse a essa classe a organização da oração, mas compreendemos que, para, novamente, simplificar, deixou de esmiuçá-lo, tanto quanto o fora na para os alunos mais maduros. Somente depois de vasta explanação acrescenta: "Predicado indica a ação ou qualidade que se atribui ao sujeito. 0 predicado é representado por palavras que se chamam verbos." (p. 14). De toda forma, lembramos que, no início de sua obra, informara que a sintaxe era a parte mais importante de gramática.

Só então passa, efetivamente, para o verbo, ensinando, apoiado em Port Royal, que ele indica: qualidade, Pedro é estudante; ação, dividindo-se em transitivos e intransitivos. Explica em nota que os verbos que trazem dois pronomes, como eu me arrependo, trazem voz média, apoiado na gramática latina. Como fizera na Gramática Portuguesa (Curso Superior) ainda nessa edição, volta a referir-se ao verbo ser: "O verbo ser é um verbo único na sua classe, porque só exprime predicação ajuntando-se a um qualificativo [...]" (p. 39).

Termina essa parte discorrendo brevemente sobre preposição, conjunção e interjeição. Ao final de cada tópico, apresenta um pequeno texto para localização da classe ensinada e sua classificação de acordo com o ministrado. Julgamos sua proposta avançada para a época, pois seus contemporâneos traziam como atividades rol de palavras e não textos.

Observamos, finalmente, que, apesar de ter inscrito as palavras em nove categorias, trata de oito, avaliando os pronomes nos determinativos.

\section{Das formas}

$\mathrm{Na}$ terceira parte de sua obra, que compreende o estudo das formas dos vocábulos, João Ribeiro explica:

6 Essa edição fora revista e corrigida inúmeras vezes, como informa sua contracapa, portanto não quer nos parecer que tenha sido erro de edição, mas vontade do autor. 
No estudo da forma (morfologia) examinaremos os elementos ou partes dos vocábulos. Trata-se não de letras, ou vozes ou sílabas que nada exprimem, mas de letras, vozes ou sílabas que têm qualquer sentido separadamente. Na palavra sobremesa por exemplo, há dois elementos significantes, um que é sobre (em cima, ou depois) e outro que é mesa. (p. 47, grifos do autor).

Por essa explanação e dada a ocasião, podemos imaginar que o autor já tivesse, de alguma forma, tido contato com a obra de Saussure.

Continuando, afirma que são dois os componentes das palavras: o radical e os afixos (prefixos e sufixos), apresentando uma vasta relação de prefixos portugueses, latinos e gregos. Também é vasta a relação de sufixos elencados na obra, os quais, a julgar pela época, deveriam ser Memórias gramaticais decorados pelos alunos.

Parte para a flexão, estudando a dos nomes, em gênero, número e grau. Em relação a este, como fizera na obra para o Curso Superior, ensina que: "Não há em português uma flexão definida: mas há sufixos mais ou menos frequentes usados e outros modos pelos quais se exprime o grau dos nomes." (p. 67). Anos mais tarde, Mattoso Câmara $\mathrm{Jr}^{7}$ sugeriria que, na língua portuguesa, esse é muito mais um caso de derivação do que de flexão, confirmando-nos a sensibilidade de João Ribeiro para os fatos gramaticais. Apesar disso, trata o comparativo e o superlativo, ensinando, inclusive as formas eruditas.

$\mathrm{Na}$ flexão do verbo, é também vasto e minucioso, ocupando 30 páginas das 130 da obra infantil, mais uma vez mostrando a importância dada a esse vocábulo.

Nessa parte, ao final de cada tópico, também apresenta propostas de exercícios, que visam à memorização do que fora exposto, como se pode notar pelo a seguir transcrito (p. 90):

\section{Exercício 28}

1. Fazer os alunos conjugar por escrito os verbos auxiliares.

2. O mesmo exercício oralmente.

3. Fazer o aluno conjugar um verbo regular de cada conjugação, e depois o verbo pôr ou um seu composto - por escrito.

4. Idem, oralmente.

7 Estrutura da Língua Portuguesa (1970). 
5. Dar uma forma verbal para que o aluno a determine (pret. imperf. do subjuntivo do verbo louvar). E vice-versa.

Com esses exercícios repetidos várias vezes, o aluno conseguirá conhecer todo o mecanismo da conjugação portuguesa.

Como já dissemos, começavam a circular à época ideais da Escola

Leonor Lopes

Fávero

Márcia A. G. Molina

64

A escola antiga era o lugar onde se ensinava exclusivamente a ler e a escrever pelos métodos mais enfadonhos e fatigantes [...]. O aluno era então uma unidade impessoalíssima, uma coisa a nivelar na comunhão geral. Idênticos todos para os mestres eram tratados sempre como unidades da mesma espécie, sem atenção à idade, a condições orgânicas, a capacidade nem a possibilidade educativas [...]. (CARNEIRO LEÃO, 1917, p. 95).

Enclausurados os estudantes em salas [...] aprendendo de memória cousas abstratas e inúteis e perpetuamente contrafeitos, pouco ou quase nada, adiantavam num conhecimento sólido, comprometendo a saúde e a felicidade. [...]. (CARNEIRO LEÃO, 1917, p. 97).

Quer tenha sido por comungar com essas questões, quer por estar atrelado ao ensino tradicional, o autor, repetidas vezes, propôs em seu compêndio exercícios de repetição tanto para serem escritos quanto para serem oralizados.

No exercício que encerra essa parte, o autor evoca o professor para que auxilie os alunos: "Dar os particípios dos seguintes verbos [...]. Estes exercícios só poderão ser feitos pelo aluno com as sugestões do professor, indicando os particípios por analogia, de outros verbos." (p. 101).

\section{Sintaxe}

Na parte final de sua obra, o autor estuda a sintaxe, classificando as proposições em simples e compostas. Nas simples, retoma a conceituação 
de sujeito e predicado, já apresentada anteriormente, adotando a orientação similar à apresentada na gramática de inspiração filosófica:

Proposição é todo agrupamento de palavras que formam juízo.

Sujeito é o ser de que se afirma algo.

Predicado é aquilo que se afirma do sujeito. (p. 103-104).

E ainda encontrada em muitos manuais hodiernos.

João Ribeiro passa depois a classificar as proposições compostas, a discorrer sobre colocação e concordância, atendendo ao objetivo da gramática, ensinar a escrever e ler corretamente. Apesar de obra dirigida à criança, pouca diferença há de conteúdo nessa parte entre ela e a de Curso Superior. A importante diferença é que esta traz, também, ao final da exposição do conteúdo, propostas de exercícios, cujos enunciados são bastante similares: "Corrigir os defeitos de colocação do seguinte trecho... Corrigir os defeitos do seguinte trecho..." Os trechos são pequenos textos que apresentam desvios sutis do conteúdo ministrado.

São dados também usos sintáticos relativos à parte do discurso, momento em que o autor ensina a sintaxe das classes das palavras.

Nesta, e somente nesta parte da obra, o autor oferece ilustrações. Quando, por exemplo, discorre sobre as preposições, oferece figuras ilustrativas do uso de na, em, com, de entre, como nos exemplos a seguir:

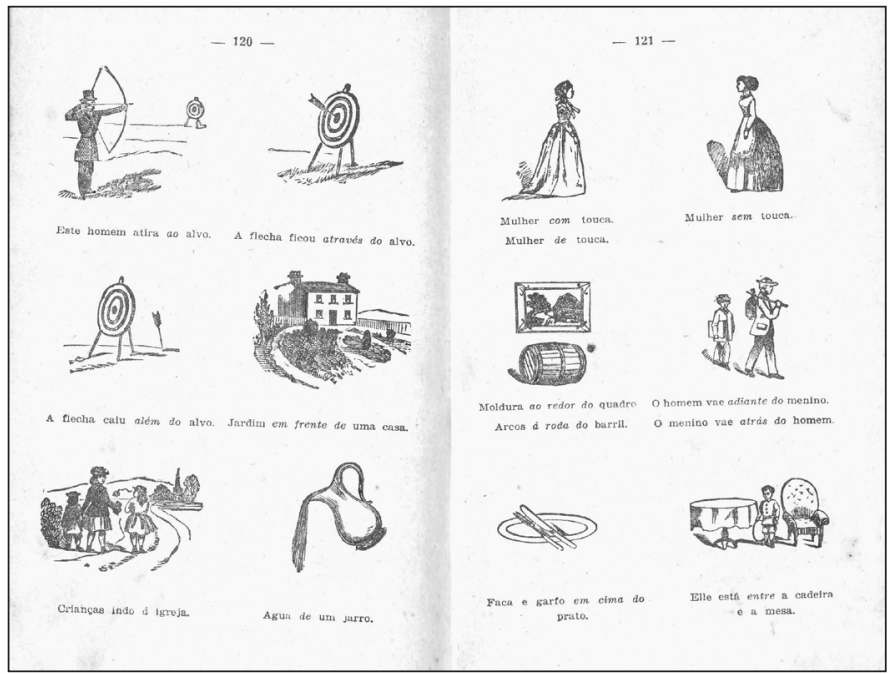

Figura 3 - Ilustração constante no estudo das preposições 
O livro de João Ribeiro é encerrado com a discussão de alguns vícios de linguagem: barbarismo, solecismo e cacófato, poucos, em relação à obra dedicada ao Curso Superior, e com anotações sobre ortografia.

\section{Considerações finais}

Nosso objetivo neste trabalho foi o de revisar duas obras gramaticais

Leonor Lopes

Fávero

Márcia A. G. Molina de João Ribeiro, uma produzida para o Curso Superior e outra para o Curso Primário. Ao final de nossas análises, podemos afirmar que na primeira o autor é mais denso no tratamento gramatical, apresentando os fenômenos gramaticais com mais acuidade. $\mathrm{Na}$ indicada para o Curso Primário, apresenta praticamente o mesmo conteúdo, mas abordando o que julga ser essencial para a idade. Além disso, na obra para criança traz, ao final de cada tópico ensinado, uma relação de exercícios a serem realizados, o que não ocorre na outra. Observamos que, inclusive, na parte de sintaxe, apresenta ilustrações.

Em ambas o objetivo da obra é ensinar a escrever de acordo com o padrão culto e, para isso, o autor revela apego ora à gramática de inspiração filosófica ora à de inspiração histórico-comparativa (mais na de Curso Superior). Em ambas demonstra considerar o verbo a palavra por excelência, já que despende para o estudo desse vocábulo parte considerável de suas obras.

Ressalte-se o cunho vernaculista das obras e o grande conhecimento que o autor tinha de nosso idioma.

Por fim, sua leitura permitiu-nos resgatar um ponto de nosso passado gramatical e inscrever as obras em nossa História das Ideias Linguísticas.

\section{Referências}

BAKHTIN, M. Marxismo e filosofia da linguagem.10. ed. São Paulo: Hucitec-Annablume, 2002 [1975].

BARROS, J. de. Gramática da língua portuguesa. Reprodução fac-similada. Leitura, Introdução e Anotações por Maria Leonor Carvalhão Buescu. Lisboa: Faculdade de Letras da Universidade de Lisboa, 1971 [1540]. 
CÂMARA JR., J. M. Estrutura da língua portuguesa. Petrópolis: Vozes, 1970.

Problemas de linguística descritiva. Petrópolis: Vozes, 1969.

CARNEIRO LEÃO, A. o Brasil e a educação popular. Rio de Janeiro: Tipografia do Jornal do Comércio, 1917.

FÁVERO, L. L. As concepções linguísticas no século XVIII: a gramática portuguesa. Campinas: Ed. da Unicamp, 1996.

; MOLINA, M. A. G. O adjetivo em João Ribeiro. In: SIMPÓSIO MUNDIAL DE ESTUDOS DE LÍNGUA PORTUGUESA, 1., 2008, São Paulo. Anais... São Paulo: USP, 2008.

LUZURIAGA, L. História da educação e da pedagogia. São Paulo: Companhia Editora Nacional, 1970.

POLLAK, M. Memória, esquecimento, silêncio. Estudos Históricos, Rio de Janeiro: Vértice, n.3, p.3-15, 1989.

REIS LOBATO, A. S. Arte da grammatica da língua portugueza. Lisboa: Regia Officina Typographica, 1770.

RIBEIRO, J. Gramática portuguesa. 11. ed. Rio de Janeiro: Livraria Francisco Alves, 1904 [1887].

Gramática portuguesa (Curso Primário). 94. ed. Rio de Janeiro: Livraria Francisco Alves, 1937 [1888].

RICCOEUR, P. La mémoire, l'histoire, l'oubli. Paris: Le Seuil, 2000. VECHIA, A.; LORENZ, M. (Org.). Programa de ensino da escola secundária brasileira (1850-1951). Curitiba: Editora do Autor, 1998. 